\title{
Nagy Anita: A tisztességes eljáráshoz való jog az Emberi Jogok Európai Bírósága Magyarországgal kapcsolatos gyakorlatában, különös tekintettel az ésszerü határidő követelményére
}

Debreceni Jogi Mühely, 2011. évi (VIII. évfolyam) 3. szám (2011. július) 31-41.

\section{Bevezetés}

Az Európa Tanács az emberi jogok és alapvető szabadságok védelmére alkotta meg 1950. november 4-én máig ható legjelentősebb dokumentumát, az emberi jogok és alapvető szabadságok védelméről szóló Egyezményt, amely az aláíró államok számára „az Emberi Jogok Egyetemes Nyilatkozatában foglalt egyes jogok kollektív biztosításának útján az első lépéseket" jelentette. ${ }^{1}$

Az egyezmény kötelezi az államokat, hogy biztosítsák a benne meghatározott jogokat és szabadságokat a joghatóságuk alatt élő minden egyén számára. Ezen túlmenően az egyezmény olyan nemzetközi ellenőrzési rendszert hozott létre, melynek értelmében az államok és a magánszemélyek, nemzetiségre való tekintet nélkül, az egyezmény alapján Strasbourgban müködő jogi intézményhez folyamodhatnak, ha úgy vélik, hogy az egyezményben garantált jogokat valamely részes állam megsértette. ${ }^{2}$ Fontos kiemelnünk, hogy az Emberi Jogok Európai Bíróságához (továbbiakban: Bíróság) közvetlenül fordulhatnak a magánszemélyek. Különösen jelentős, hogy a Bíróság ítéletei a tagországok számára kötelező érvényüek. Azonban szükséges kihangsúlyozni, hogy a strasbourgi fórumra semmiképpen sem lehet úgy tekinteni, mint az ügy érdemében döntő negyedik bírósági szintre.

Ha létezik jellegzetesen magyar ügy, akkor a jogi eljárások elhúzódásával kapcsolatos panaszok kétség kívül ilyeneknek tekinthetők. ${ }^{3}$ A témámul választott 6 . cikk az Emberi Jogok Európai Bíróságának felállítását követő évtizedekben az Egyezményben elfoglalt központi szerepét emeli ki, hogy vonatkozásában keletkezett a legterjedelmesebb esetjog, amit alátámaszt az a tény, hogy vannak olyan cikkek, amelyeknek bizonyos tagállamok soha nem váltak érintettjeivé, míg a 6. cikk vonatkozásában egyetlen tagállam „érintetlensége” sem állapítható meg. Hazánk 1992. november 5-én ratifikálta az Egyezményt, aminek következtében a magyarországi jogrendszert befolyásoló tényezővé váltak a Bíróság döntései.

\section{Az Emberi Jogok Európai Bírósága előtt folyamatban lévő magyar vonatkozású ügyek a számok tükrében}

Először vizsgáljuk meg a Bíróság által követett elintézési időtartamokat:

A Magyarországról érkező panaszok számát más kelet-közép európai országokból érkező panaszok számával összehasonlítva megállapítható, hogy a magyar jogrendszer által biztosított emberi jogi védelem hatékony annak ellenére, hogy a Bíróság elé érkező ügyek száma folyamatosan növekvő tendenciát mutat. Az elmúlt évek adatait áttekintve megállapítható, hogy Csehország, Szlovákia, Horvátország ellen - figyelembe véve a lakosság számát is - több panasz érkezett a strasbourgi bíróság elé, mint Magyarország ellen. ${ }^{4}$ A Bíróság honlapján közzétett statisztikai adatokat vizsgálva szembetünő az elfogadhatatlan kérelmek nagy száma, aminek oka lehet, hogy a strasbourgi bíróság joggyakorlatának ismerete ugyancsak hiányos. Az ügyek legnagyobb része sohasem jut el a kamarákig, 2010 óta nagyobb részben egyesbíró, ritkábban háromtagú tanács fogja őket elfogadhatatlannak minősíteni. Ezekben az egyszerübb esetekben nagyjából 1-1,5 év az az időtartam, amit követően az érintett megkapja az ügy elfogadhatatlanságáról szóló rövid értesítő levelet. ${ }^{5}$ 
Az 1980-as évek elejétől kezdődően gyors ütemben nőtt a beterjesztett keresetek száma, ami a rendszer túlterheléséhez, valamint a panaszos ügyek kivizsgálásának olyan mértékü meghosszabbodásához vezetett, hogy az érdemi döntés kihirdetéséig néha öt év is eltelt. ${ }^{6} \mathrm{Az}$ eljárások elhúzódásával kapcsolatos ügyek hatalmas számot tesznek ki. Ezek az ügyek annyira ismétlődő jellegüek, hogy a Bíróság is egyre inkább már csak a korábbi, hasonló tárgyú döntéseire hivatkozik részletes indoklás helyett. ${ }^{7}$

A Bíróság ítéleteiben gyakran láthatjuk, például a Frydlender v. France ügyben ${ }^{8}$ foglalt megállapításaira való hivatkozást miszerint az eljárás hosszának ésszerű voltát az eset egyedi körülményeinek fényében és az alábbi kritériumokra figyelemmel kell megítélni: az ügy bonyolultsága, a kérelmező és a releváns hatóságok magatartása, valamint a per tétje a kérelmező számára.

A hazai bíróságokat érintő magyar ügyek két fő csoportra oszthatók:

az Egyezmény 6. cikk 1. pontja szerinti, az ügyek ésszerü időn belül történő elbírálásával (a továbbiakban: eljárás-elhúzódással) kapcsolatos, valamint

az Egyezmény más cikkeiben foglalt jogok megsértése miatt benyújtott kérelmek. ${ }^{9}$

2010. december 31-én a Kormányképviseleten folyamatban lévő 66 ügyből pedig 46 indult eljárás-elhúzódás miatt. A Magyar Állam 2010-ben 83 millió Ft-ot fizetett ki a kérelmezők részére. Az idézett államtitkári tájékoztató mellékletében felsorolt 46 eljárás-elhúzódási ügy közel felében a hazai bírósági szakasz időtartama meghaladta a 10 évet. Az EJEB 2010. második félévben meghozott 13 ítéletéből 6 ügynek, továbbá 11 egyezséget jóváhagyó határozatnak volt tárgya a bírósági eljárások elhúzódása. 2010. december 31-én a Kormányképviseleten folyamatban lévő 66 ügyből pedig 46 indult eljárás-elhúzódás miatt. ${ }^{10}$

\section{Az Egyezmény 6. cikke által biztosított tisztességes eljáráshoz való jog}

Magyarországról a Bírósághoz fordulók leggyakrabban a magyar bíróságok elfogultságát sérelmezik és kérik, hogy a strasbourgi fórum állapítsa meg a tisztességes eljáráshoz füződő joguk megsértését, azonban hangsúlyozni szükséges, hogy ebből az okból kifolyólag kártérítés fizetésére még nem kötelezte hazánkat a Bíróság. A 6. cikk teljes áttekintésének terjedelmi korlátait figyelembe véve, csak az emberi jogok garanciális érvényesüléséhez szükséges legalapvetőbb elemeket mutatom be:

\section{„,Mindenkinek joga van arra, hogy ügyét a törvény által létrehozott független és pártatlan} bíróság,"

A törvény által létrehozott bíróság követelménye értelmében a bíróságokról jogszabályoknak kell rendelkeznie, biztosítva ezáltal a végrehajtó hatalomtól való függetlenséget. A pártatlanság olyan szoros összefüggésben áll a függetlenség követelményével, hogy azok elemzését a Bíróság sem választja szét.

A bírák függetlenségét az államnak nem csupán az államhatalmi ágak elkülönülésének relációjában, objektív alapon kell biztosítania, hanem szubjektíven is azáltal, hogy a bíróságok tagjai személyes elöítéleteiktől mentesen tudjanak ítéletet hozni. A hazai bíróságoknak tehát kettős próbát kell kiállni. A szubjektív teszt keretében a bíróság az eljáró bíró személyes magatartását, vagyis azt vizsgálja, hogy volt-e az eljárás során olyan megnyilvánulása, amelyből a pártatlanságának a hiányára lehet következtetni. Az objektív teszt pedig annak a vizsgálatát jelenti, hogy a bíró személyes magatartásától függetlenül, a panaszosnak volt-e jogos, indokolt, objektív szempontból is igazolható oka a pártatlanság hiányát feltételezni. ${ }^{11}$ 
A bíróság eljárása nem lehet alkalmas arra, hogy kételyeket ébresszen a bíróság pártatlanságának tekintetében. Az Alkotmánybíróság által is leszögezett alapvető elv szerint ugyanis "a bírónak nemcsak pártatlannak kell lennie, hanem pártatlannak is kell látszania. "12

Az egyezmény szempontjából az alábbi feltételek együttes fennállása esetén tekinthető egy bíróság függetlennek. Egy ilyen bíróság ítélkező funkciót gyakorol; független a felektől, a törvényhozó és a végrehajtó hatalomtól; a tagjait megfelelő eljárásban és viszonylag hosszabb időre nevezik ki; összetétele nem önkényes; eljárása törvényes; tagjainak senki sem adhat utasítást, illetve tagjai más külső befolyás ellen is védve vannak; végül függetlenségének a látszata is biztosított. ${ }^{13}$ A felsorolásból kitünik, hogy az objektív kritériumokon felül még a függetlenség látszatának is meg kell felelnie egy nemzeti bíróságnak.

\section{„tisztességesen, nyilvánosan,”}

Az eljárás tisztességének követelményének sérelmét a Bíróság csak akkor tartja megállapíthatónak, ha azt a per későbbi szakaszaiban sem orvosolták. A tisztességes eljárás hiánya megállapítható például, ha az eljárásban a felek számára nem volt biztosítva a felek egyenjogúsága, mellérendeltsége, illetve a megfelelő részvétel.

Ami a tárgyalás nyilvánosságát illeti, főszabály szerint nyilvános tárgyalásnak lennie kell. E jogról az érintett lemondhat akár kifejezetten, akár hallgatólagosan, e lemondásnak azonban valamennyi érintett vonatkozásában egyértelmünek kell lennie, és nem sérthet közérdeket. ${ }^{14} \mathrm{~A}$ fellebbviteli bíróságok tekintetében a tárgyalás nyilvánosságának követelménye korlátozottabban érvényesül, az azonban megállapítható, hogy kizárólag jogkérdésben döntő felsőbíróság előtt általában nincs szükség nyilvános tárgyalás tartására.

Az ítélet kihirdetésével kapcsolatban az Egyezmény 6. cikke szintén megköveteli a nyilvánosságot, ami az ítélet rendelkező részének és az indokolás lényegének ismertetését foglalja magában. A nyilvánosság védelmet biztosít a feleknek, továbbá segít megerősíteni a bíróságokba vetett bizalmat.

„,ésszerü időn belül tárgyalja, és hozzon határozatot polgári jogai és kötelezettségei tárgyában, illetöleg az ellene felhozott büntetöjogi vádak megalapozottságát illetően.”

Az ésszerü idő követelményének kifejtésére részletesen kitérek a következő címben. Ami a polgári jogok és kötelezettségek fogalmi megítélését illeti, azokat a Bíróság a nemzeti jogoktól függetlenül határozza meg, aminek során természetesen figyelembe veszi a belső jog szerinti minősülést, mivel arra nincs lehetősége a Bíróságnak, hogy egy a belső jogban nem létező jogot keletkeztessen. A Bíróság nem teremthet tehát jogalapot olyan kérdések megvitatása tekintetében, amelyek az Egyezményből nem vezethetők le, és amelyeket a belső jog sem szabályoz polgári jogként. ${ }^{15}$ Nehézségeket okozhat a polgári jog és közjog elhatárolása, amely gyakran igen nehéz feladatot ró a Bíróságra, tekintettel arra, hogy a közjogi jellegü ügyek nem tartoznak a 6 . cikk hatálya alá.

A büntetőjogi vádak megalapozottságát illetően kiemelném, hogy itt sem a nemzeti jog fogalom-meghatározása a Bíróság kiindulópontja. A Bíróság a „vád” fogalmát úgy határozta meg, mint ,az arra jogosult hatóságtól származó, a büncselekmény elkövetésének a személlyel való hivatalos közlését” amelyhez még hozzátette, hogy „,a vád egyes esetekben más típusú, a személy helyzetére komoly hatással bíró ilyen jellegü állításokat magában foglaló intézkedések formájában is megjelenhet."16

Gyakran nagyon fontos annak pontos meghatározása, hogy mikor emelték a „vádat”, mivel ettől az időponttól kezdődik a 6 . cikk 1. pontjában meghatározott ésszerü határidő. ${ }^{17}$ 


\section{A Bírósághoz fordulás feltételei}

Az Egyezmény 35. cikkének 1. pontja szigorú követelményeket támaszt a panaszosok számára, aminek értelmében a Bírósághoz fordulás az összes hatékony hazai jogorvoslat kimerítése után számított hat hónapon belül lehetséges. A gyakorlatban problémát okoznak a felülvizsgálati kérelmek, ugyanis egy érdemi vizsgálatra alkalmatlan felülvizsgálati kérelem veszélybe sodorhatja a hat hónapos határidő betartását. A felülvizsgálati eljárás mellőzésével viszont a Bíróság elutasítását kockáztatja a panaszos.

A hathónapos szabály alkalmazásánál is szigorú a Bíróság. Amennyiben a kérelmező az utolsó érdemi döntés kézhezvételétől számított hat hónapon túl nyújtja be beadványát, úgy a Bíróság érdemi vizsgálat nélkül elutasítja a kérelmet. Figyelmet érdemel, hogy az Egyezmény magyar szövege kerüli a jogerős szót, amikor meghatározza azt a határozatot, melynek meghozatalát számított hat hónapon belül van lehetőség a panasz előterjesztésére. ${ }^{18}$

\section{Az ésszerü határidő vizsgálatának problematikája}

A jogalkalmazók, a bírósági eljárásban részvevő személyek gyakran szembesülnek azzal a ténnyel, hogy a bíróság előtt folyamatban lévő ügyek hosszú évekig elhúzódnak. Az eljárás ésszerütlenül hosszú időtartama megrendíti a jogbiztonságot, megkérdőjelezheti az egyénnek az igazságszolgáltatásban vetett hitét. ${ }^{19}$

Vizsgáljuk meg, hogy miként járul hozzá a strasbourgi ítélkezés a 6. cikkben biztosított emberi jogok érvényesüléséhez továbbá, hogy milyen problémák merülnek fel egy olyan nehezen behatárolható tényező kapcsán, mint az eljárás időtartama.

Az ésszerü határidő betartásának követelménye szempontjából az egész eljárás képezi a vizsgálat tárgyát, aminek következtében megfogalmazódik a kérdés, hogy mikortól meddig tart a vizsgálat alá vonandó időszak. Az eljárások elhúzódását sérelmező kérelmek esetében a Bíróság a nemzeti bíróság előtt még folyamatban lévő eljárásokat is érdemi vizsgálat alá veszi. $^{20}$

A Bíróság által vizsgálat ügyek egy részének pertartamának kezdete szempontjából jelentősége van az Egyezmény ratifikálásának időpontjának. A strasbourgi gyakorlat ezekben az esetekben is vizsgálat alá vonja a ratifikálást megelőző eljárást. Bár az Egyezmény hatálybalépése előtt bekövetkezett tényekért az állam nem felelős, így ez az időtartam szigorúan véve nem számítana bele az eljárás vizsgált időtartamába. ${ }^{21}$

Polgári jogi téren a kiindulási pont rendes körülmények között a per bíróság előtti megindulásának időpontja, de ez lehet korábbi is, például ha a bírósági eljárás megindítása előtt előzetesen lefolytatandó közigazgatási eljárás volt. ${ }^{22}$

Büntető ügyben az érdekeltnek a 6. cikk 1. pontja szerinti értelemben első alkalommal történő „megvádolásával kezdődik” ez az időszak; szóba jöhet az ítélőbíróság előtti eljárást megelőző dátum is (mint például a letartóztatás ideje). ${ }^{23}$

Az eljárás befejező időpontjának meghatározása is nehézségekbe ütközik, azonban az eljárás elhúzódásával kapcsolatos kérelmek befogadhatóságának nem feltétele, hogy az ügy befejeződjön, ugyanis folyamatban lévő ügyekben is lehetséges a strasbourgi bírósághoz való fordulás. A Bíróság gyakorlata az eljárás végének az utolsó érdemi döntést tekinti. Azonban a Bíróság az eljárási szakasz részének tekinti az ítéletek végrehajtását is, aminek következtében előfordulhat, hogy az elhúzódó végrehajtás alapozza meg 6. cikk 1. pontja szerinti egyezménysértés megállapítását, annak ellenére, hogy a bíróság előtti eljárás időtartama megfelelt a 6. cikkben megfogalmazott követelménynek. Újabb kérdésként fogalmazódik meg az eljárás felfüggesztésének, szünetelésének időtartamának figyelembe vétele. Általánosságban megállapítható, hogy a Bíróság ezeket az időintervallumokat egészében beleszámítja az eljárás időtartamába, amennyiben az állam felelőssége megállapítható. A Tót 
kontra Magyarország és Olaszország ügyben ${ }^{24}$ a Bíróság a munkaügyi per időtartamából levonta a több mint 6 éves olaszországi eljárás hosszát, mivel a magyar bíróság felelőssége nem megállapítható az olasz eljárás elhúzódásáért. A Borody kontra Magyarország ügyben ${ }^{25}$ a felek kérelmére elrendelt szünetelés idejét vonta le a Bíróság a bírósági eljárás hosszából, tekintettel arra, hogy az nem róható az állam terhére.

A Bíróság a Börcsök Bodor kontra Magyarország ügyben ${ }^{26}$ is kifejtette, hogy a Bíróság az eljárás hosszának ésszerü voltát az eset egyedi körülményeinek fényében, a Bíróság esetjogában lefektetett kritériumok figyelembe vételével kell megítélni, különös tekintettel az eset bonyolultságára, a kérelmező és a releváns hatóságok magatartására és arra, hogy mi volt a per tétje a kérelmező számára.

A Bíróság bizonyos ügyeket kiemelten kezel, a munkaügyi, kártérítési, gyermekelhelyezés, gyermektartás, személyi szabadságot korlátozó kényszerintézkedés, ezekben az esetekben a bíróság az eljárás 5 éves tartamát is jogsértőnek tartja. A Bíróság maga is különös figyelmet fordít a felsorolt típusú ügyekben történő döntéshozatalára. Az eljárás tétje szerint általában különös gyorsasággal lefolytatandónak minősülnek a munkaviszonnyal kapcsolatos jogviták, a családi jogállással, cselekvőképességgel kapcsolatos ügyek és egyes kártérítési perek. Azok az esetek is ebbe a csoportba tartoznak, amelyekben a késedelem az eljárás célját veszélyezteti. ${ }^{27}$

A strasbourgi bíróság az ésszerű időtartam betartását kifogásoló minden egyes panaszban konkrét vizsgálatot folytat, és az elmarasztaló vagy jóváhagyó döntését az eljárás összes körülményének alapos elemzése alapján hozza meg. Egy vizsgálat során több tényezőt is figyelembe vesz:

- az ügy objektív bonyolultsága, komplexitása vagy esetleges olyan egyéb összetevői, amelyeknek az eljárás időtartamára számottevő befolyása lehet,

- a felek magatartása az eljárás során abban a tekintetben, hogy esetleges felróható magatartásukkal nem járultak-e hozzá maguk is az eljárás elhúzódásához,

- végül az érintett állam közhatalmi szerveinek saját magatartása abban a vonatkozásban, hogy mennyire felelősek az eljárás elhúzódásáért. ${ }^{28}$

Az ügy bonyolultsága: Ami az ügy bonyolultságát illeti, polgári perekben nem egyszer előfordul, hogy a hatóságoknak bonyolult ténybeli vagy jogi megítélésű perekkel, száznál több ügyféllel, nemzetközi vonatkozásokkal, sok ezer oldalas iratanyagokkal kell megbirkózniuk. ${ }^{29}$ A Bíróság az ügy bonyolultsága tekintetében csak nagyon ritkán fogadja el az arra vonatkozó hivatkozást. Azokban az estekben azonban, amikor egy konkrét ügy jogi és ténybeli megítélése indokolja, az akár 8-10 évig elhúzódó perek esetén sem állapít meg jogsérelmet a bíróság. Természetesen az ésszerü eljárási időtartam elfogadásának elengedhetetlen feltétele, hogy se a kérelmező, se az állami szervek vonatkozásában ne legyen megállapítható jelentős, indokolatlan késedelem.

A felek magatartása: Ami a peres felek saját magatartását illeti, ennek két összetevőjét vizsgálják az eljárás ésszerü időtartama szempontjából. Egyrészt figyelemmel vannak arra, hogy az érintett késleltette-e saját magatartásával az ügy előremenetelét, másrészt azt vizsgálják, hogy megtett-e minden tőle telhetőt az eljárás meggyorsítása érdekében. Az előbbinek nyilván nagyobb a súlya, hiszen míg az eljárást sokféleképpen lehet feleslegesen késleltetni, addig az ügyfeleknek hatékony eszközök nemigen állnak rendelkezésére az eljárás felgyorsítása érdekében. ${ }^{30}$ A Bíróság ugyancsak vizsgálja azt, hogy a hazai bíróság kellő eréllyel fellépett-e a rendelkezésre álló eszközeivel a felek perelhúzó magatartásának megelőzése vagy szankcionálása érdekében. ${ }^{31}$ A magánfélnek betudható késedelem vonatkozásában az állam közvetlenül nem felelős, azonban vizsgálat tárgyát képezi, hogy a bíróság megtette-e a szükséges intézkedéseket az eljárás felgyorsítása érdekében. Az a tény, 
hogy polgári ügyben a peres felek felelősek az eljárás irányításáért, menetéért, nem mentesíti a bírókat a gyors pervitel biztosítása alól. ${ }^{32}$ A panaszos terhére esnek az indokolatlan elfogultsági kifogások, ha kereseti kérelmét ok nélkül sokszor módosítja, továbbá az is, ha a szabályszerü idézés ellenére nem jelenik meg a kitüzött tárgyaláson és távolmaradását kimenteni nem tudja. ${ }^{33}$ Amennyiben a panaszos magatartása miatt nem haladt az ügy, úgy a Bíróság a panaszosnak felróható késedelem időtartamát levonja a teljes eljárás hosszából. A Bíróság nyilvánvalóan megalapozatlannak ítélte a panaszt a Horváth kontra Magyarország ügyben ${ }^{34}$, tekintettel arra, hogy a hét év és három hónapos időtartamból a panaszosnak három év és nyolc hónap felróható volt.

Az érintett államok magatartása: A strasbourgi bíróság az állam közhatalmi szerveinek vonatkozásában az eljárás elhúzódásáért fennálló felelősség megállapíthatóságát vizsgálja. Ebben az esetkörben a legjellemzőbb probléma az érdemi tárgyalások között eltelt szünetek.

Például a Tóth László kontra Magyarország ügy ${ }^{35}$ alapjául szolgáló munkaügyi perben a hazai bíróság több mint három évig egyetlen tárgyalást sem tartott, bár néhány eljárási intézkedést tett. Ezt követően ugyan rendszeresen tartottak tárgyalásokat, de a Bíróság szerint „,a nemzeti bíróságok nem használták ki a rendelkezésükre álló időt arra, hogy az ügyek mielőbbi lezárása érdekében felgyorsítsák az eljárást", így az eljárás teljes hosszára, a munkaügyi perek különleges jelentőségére és az említett inaktív időszakra tekintettel kimondta az Egyezmény 6. cikk 1. pontjának megsértését és kártérítést szabott ki. ${ }^{36}$

$\mathrm{Az}$ érintett államok gyakran hivatkoznak a bíróságok túlterheltségére, finanszírozási nehézségekre, adminisztrációs problémákra, azonban a fentiekben felsorolt kimentési okokat a strasbourgi bíróság nem találja elfogadhatónak, mivel az állam kötelezettsége, hogy hatékony jogvédelmi rendszert müködtessen.

Nem érinti az érintett államot, illetve közhatalmi szerveit, hogy a mulasztásért esetleg csak közvetett módon felelős. Elmarasztalás alapjául szolgált egyebek között olyan körülmény is, hogy a kirendelt szakértő 16 hónapon át nem terjesztette elő a szakvéleményét. E körben az érintetteknek meg lehetett ugyan az elvi lehetősége, hogy másik szakértő kirendelését kérjék az eljáró bíróságtól, ilyen kötelezettség azonban nem terhelte őket, így az ezzel kapcsolatos perelhúzó magatartás nem volt terhükre róható. E körben a felelősség a kirendelő bíróságot terhelte. $^{37}$

Abban az esetben, ha a Bíróság megállapítja a panaszos Egyezményben foglalt jogának sérelmét a tagállam által fizetendő kártérítés is megítélhető. Azonban erre csak a panaszos fél határozott kérelme esetén kerülhet sor, ugyanis kártérítés megállapítására vonatkozó kérelem hiányában a Bíróság nem rendelkezhet a fizetendő jóvátételről.

Hasonló a helyzet a Bíróság eljárása alatt felmerült költségek tekintetében is. Ebben az esetben is elengedhetetlenül szükséges a határozott kérelem, továbbá a költségek felmerülését bizonyítékokkal is alá kell támasztani.

Számos hossz-ügy ér véget a panaszos és a Kormány közötti békés megegyezéssel. A megegyezés lényege, hogy a Kormány meghatározott összegü kártalanítást fizet a panaszosnak, aki ennek fejében eláll a további strasbourgi eljárástól. Feltétlenül érdemes a panaszosoknak békés megállapodásra törekedni, ugyanis így sokkal gyorsabban - akár kéthárom évvel hamarabb - jutnak a pénzükhöz, másfelöl a Kormány általában magasabb kártérítési összeget kínál fel, mint amit a Bíróság később valószínűsíthetően megítélne. ${ }^{38} \mathrm{~A}$ Bíróság tudomásul veszi a megegyezést, és a nyilvántartásból való törlést elrendelő határozattal befejezi az ügyet. 


\section{Egyezmény 6. cikk 1. pontja alapján bemutatott magyar ügyek}

A Bíróság Hesz György Magyarország elleni ügyében ${ }^{39}$ az Egyezmény magyarországi ratifikálásának időpontjának megítélését, továbbá a per felfüggesztésének időtartamának a teljes pertartam számításánál történő figyelembevételét vonta vizsgálat alá.

Hesz György 1992. szeptember 10-én szerződés érvénytelenségének megállapítása, illetve az alperesek által lakott ház kiürítése iránt keresetet terjesztett elö a Budapesti XX., XXI. és XXIII Kerületi Bíróság előtt. A bíróság több tárgyalás tartását követően a pert 1997. február 4-e és 1999. május 20-a közötti időtartamra egy földhivatal elött folyamatban lévő eljárás jogerős befejezéséig felfüggesztette. Végül a bíróság 2004. június 30. napján - újabb tárgyalásokat követően - a keresetet elutasította. A másodfokú bíróság 2005. április 13-án az elsőfokú határozatot érdemben helybenhagyó döntést hozott. Ezt követően a Legfelsőbb Bíróság 2006. április 4-én a panaszos felülvizsgálati kérelmét elutasította.

A panaszos az Egyezmény 6. cikkének (1) bekezdésében foglalt "ésszerü idő" követelményének megsértésére hivatkozott. A Bíróság megjegyezte, hogy a figyelembe veendő időszak 1992. november 5-én vette kezdetét, amikor az egyéni panaszjog Magyarország általi elismerése hatályba lépett. Az azt követően eltelt idő ésszerüségének értékelése során azonban figyelembe kell venni az eljárás állását ebben az időpontban. A Bíróság megállapította, hogy az ügy a hatálybalépéskor már mintegy két hónapja folyamatban volt. A szóban forgó időszak 2006. április 4-én ért véget, vagyis tizenhárom évig és hét hónapig tartott. Ebből az időszakból, az eljárás felfüggesztésének megfelelő két év és három hónap nyilvánvalóan indokolt volt, és így nem róható fel az államnak, ezért azt a teljes időtartamból le kell vonni. Ugyanakkor a fennmaradó három bírósági szinten eltelt időszak továbbra is meghaladja a tizenegy évet és négy hónapot. A Bíróság úgy ítélte, hogy a Kormányzat nem terjesztett elő olyan tényt vagy meggyőző érvet, amely az eljárás elhúzódásának ésszerü okát adta volna, ezért megállapította, hogy az alapeljárás időtartama nem felelt meg az ,ésszerü idő" követelményének. A Bíróság tehát úgy találta, hogy az Egyezmény 6. cikkének (1) bekezdését megsértették, és a panaszosnak 8.000.-Euró nem vagyoni kártérítést ítélt meg. ${ }^{40}$

A 6. cikk által védett jogok vonatkozásában a panaszosok gyakran hivatkoznak a tisztességes eljáráshoz való joguk megsértésére, amivel kapcsolatban az igazságszolgáltatás minőségének pozitív értékelését erősíti az a tény, hogy a Bíróság az erre vonatkozó kérelmeket szinte kivétel nélkül nyilvánvalóan megalapozatlannak minősíti. Azonban az APEH Üldözötteinek Szövetsége és mások kontra Magyarország ügy ${ }^{41}$ kivételesnek tekinthető. Jelen esetben magánszemélyek kezdeményezték a bíróságnál szövetségük bejegyzését. Az eljárásról tudomást szerzett az APEH elnöke, aki a szövetség névválasztását kifogásoló panasszal élt az ügyészségnél. Az APEH elnökének kifogásairól a szövetség bejegyzésének kérelmezöit nem értesítették. Az ügyészség beavatkozóként indítványozta a nyilvántartásba vétel megtagadását. A bejegyzési eljárás elutasítással ért véget, amit a panaszosok megfellebbeztek, aminek szintén elutasító döntés volt az eredménye. A szövetség tagjai a Legfelsőbb Bírósághoz fordultak a döntés ellen. Ebben a szakaszban beavatkozóként lépett fel a Legföbb Ügyész a kérelem ismételt elutasítására irányuló indítvánnyal, erről azonban a szövetség tagjai semmilyen értesítést nem kaptak. A Legfelsőbb Bíróság elutasító döntésének következtében felülvizsgálati eljárást kezdeményeztek, amibe ugyancsak beavatkozott a Legfőbb Ügyész. A hazai eljárás eredménytelenül ért véget, aminek következtében a panaszosok az EJEB elött folytatták a harcot az igazságukért az Egyezmény 6. cikke által biztosított tisztességes eljáráshoz való joguk megsértésére hivatkozva.

A bíróság először azt a kérdést vizsgálta., hogy a beadvány egyáltalán a 6 . cikk hatály alá esik-e, a bejegyzési eljárás nemperes jellegének nem tulajdonított jelentőséget. Ez a cikk 
ugyanis csak „polgári” ügyekre mondja ki a fair eljárás követelményét, és vitatott volt, hogy az egyesület bejegyzése ilyen ügynek minősül-e. ${ }^{42}$ A Kormány védekezésében az eset közjogi jellegére hivatkozott, azonban a Bíróság azt nem találta elfogadhatónak. A fentebb már idézett Frydlender v. France ügyben tett megállapításaira hivatkozva a Bíróság megismételte, hogy a 6. cikk (1) bekezdésének alkalmazhatóságához olyan "jog" feletti vita szükséges, amelyről megfelelő érvekkel állítható, hogy a hazai jog elismeri. A vitának valódinak és komolynak kell lennie. Nemcsak a jog tényleges létezésével lehet kapcsolatos, hanem annak kiterjedésével és gyakorlásának módjával is. Továbbá, az eljárás eredményének közvetlenül döntőnek kell lennie a szóban forgó polgári jogra nézve. ${ }^{43}$ A bíróság megállapította, hogy az egyesületek bejegyzésének joga a magyar jogban elismert, illetve, hogy a vita valós és komoly. A bíróság kifejtette, hogy a társadalmi szervezetek a bírósági nyilvántartásba vétellel nyerik el azon képességüket, hogy polgári jogok és kötelességek alanyai lehessenek. A kérelmezők hivatkoztak a fegyverek egyenlőségének sérelmére, mivel sem az APEH elnöke által írt levélről, sem az ügyészség beadványairól nem kaptak tájékoztatást, illetve, hogy az APEH korábban lett értesítve az elutasító végzésröl, mint a panaszosok. A fenti tények kétségbe vonták az eljárás tisztességes voltát. A bíróság korábbi joggyakorlatára hivatkozva kiemelte, hogy az eljárás résztvevőinek lehetőséget kell biztosítani, hogy megismerhessék a felhozott bizonyítékokat és előterjesztett iratokat, és azokra észrevételt tehessenek. Mindezek alapján a Bíróság megállapította a 6. cikk 1. megsértését. Az eset kivételes jelentőségét az adja, hogy a Bíróság ebben az egyetlen esetben marasztalta el Magyarországot a tisztességes eljáráshoz való alapvető jog megsértéséért, azonban kártérítési kötelezettséget nem állapított meg.

\section{Összegzés}

Az egyezmény által védett tisztességes eljáráshoz való jog vonatkozásában a legmeghatározóbb hiányosságaink az ésszerü idő követelményének betartásával kapcsolatban merülnek fel.

Annak ellenére, hogy a magyar egyezménysértések viszonylag kis számot tesznek ki, Magyarországgal szemben is megfogalmazódik az elvárás, miszerint a bírósági eljárások elhúzódása ellen megfelelően hatékony intézkedéseket kell tenni.

Az eljárások gyorsítása, hatékonyság növelése elérendő célként szerepel a magyar joggyakorlatban. Ezen törekvés keretében iktatta be az Országgyülés a polgári eljárási törvénybe az eljárási kifogás jogintézményét.

Általánosságban megállapíthatjuk, hogy a magyar jogrendszer biztosítja a tisztességes eljáráshoz való alapvető emberi jog érvényesülését, amit alátámaszt a magyarországi egyezménysértések kis száma is.

Jelen tanulmányban megkíséreltem bemutatni az Emberi Jogok Európai Bírósága előtt folyamatban lévő magyar ügyekkel kapcsolatos adatokat, valamint a 6 . cikk által biztosított tisztességes eljáráshoz való jog érvényesülésének garanciális elemeit, továbbá a strasbourgi bíróság által követett szempontokat az eljárás-elhúzódási ügyek vizsgálata során. Végezetül a leírtakat egy tipikusnak mondható, és egy kivételesnek tekinthetö ügy kapcsán igyekeztem a Bíróság gyakorlata szempontjából is ismertetni. 


\section{Right to the fair trial in the case-law of the European Court of Human Rights against Hungary, with special regard to the requirement of reasonable period of time - Summary}

As for the right to a fair trial sanctioned by the convention, our most determining deficiencies arise regarding the compliance with a reasonable period of time. Despite of the relatively small number of the Hungarian infringements of the European Convention on Human Rights, the expectation of sufficiently efficient dispositions eliminating the prolongation of the judicial procedures applies for Hungary as well.

In general, it can be concluded that the Hungarian legal system provides the basic human right to fair trial. This claim is supported by the low number of infringements in Hungary. In this study I sought to present the data related to the Hungarian cases proceeding at the European Court of Human Rights, as well as elements warranting the emergence of the right to a fair trial assured by Article 6, together with the aspects during the monitoring of the cases of the prolongation of the judicial procedures respected by the Court of Strasbourg. Finally I aimed to delineate the aforesaid apropos of a representative and an exceptional case in respect of the practice of the Court as well.

\section{Források}

1. A Legfelsőbb Bíróság Nemzetközi Kapcsolatok és Európai Jogi Irodájának Hírlevele, I/7. Forrás: http://www.lb.hu/

2. Az Alkotmánybíróság 6/1998. (III. 11.) AB határozata.

3. GRÁD András: A strasbourgi emberi jogi bíráskodás kézikönyve, Strasbourg Bt., Budapest, 2005, 213-357.

4. KARSAI Dániel: Magyar ügyek Strasbourgban 2000-2004 között, Acta Humana, 2005/3. 26. 25-59.

5. KONDOROSI Ferenc: Az emberi jogok védelmének új kérdései, Emberi Jogok Magyar Központja Közalapítvány, Budapest, 2006, 51.

6. Közigazgatási és Igazságügyi Minisztérium (Répássy Róbert igazságügyért felelős államtitkár), Tájékoztató az Országos Igazságszolgáltatási Tanács részére az Emberi Jogok Európai Bírósága elött folyamatban lévö - a magyar bíróságok eljárásával kapcsolatos - állampolgári kérelmek intézéséröl, aktuális fejleményeiröl (XXNBSKFO/1149-2/2011.), Forrás: http://www.mabie.hu/

7. NEMES Imre: A méltányos bírósági eljáráshoz való jog az Emberi Jogok Európai Egyezményében, Forrás: http://www.drnemesimre.hu/

8. OROSZ Árpád: A magyarországi polgári perek az Emberi Jogok Európai birósága elött, Acta Humana, 2007/4. 3-24.

9. SOLT Pál: Tanulmányok az Emberi Jogok Európai Egyezménye legfontosabb rendelkezéseihez kapcsolódó strasbourgi esetjogról, hvgorac, Budapest, 1999.

10. SZABÓ Győző - NAGY Gábor: Tanulmányok az Emberi Jogok Európai Egyezménye legfontosabb rendelkezéseihez kapcsolódó strasbourgi esetjogról, hvgorac, Budapest, 1999, 92-145.

11. WELLER Mónika - TEPLÁN Attila, Magyar ügyek Strasbourgban, Acta Humana, 2000/41-42. 104-111.

12. http://www.echr.coe.int/

13. http://www.europatanacs.hu/

14. http://www.lb.hu/

15. 30979/96 sz. kérelem. 
16. 44746/04 sz. kérelem, 2008. február 5-i ítélet.

17. 44885/04. sz. kérelem, 2007. november 20-i ítélet.

18. 14962/03. sz. kérelem, 2006. október 3-i ítélet.

19. 60307/00 sz. kérelem, 2004. március 23-i elfogadhatósági határozata.

20. 60297/00 sz. kérelem, 2004. március 30-i ítélet.

21. 39382/06 sz. kérelem, november 30-i kelt ítélet.

22. 32367/96 sz. kérelem, 2000. október 5-i kelt ítélet.

\footnotetext{
${ }^{1}$ SOLT Pál: Tanulmányok az Emberi Jogok Európai Egyezménye legfontosabb rendelkezéseihez kapcsolódó strasbourgi esetjogról, hvgorac, Budapest, 1999, 5.

${ }^{2}$ Forrás: http://www.europatanacs.hu/index.php?workSpace=pages\&id=45\&langId=1

${ }^{3}$ KARSAI Dániel: Magyar ügyek Strasbourgban 2000-2004 között, Acta Humana, 2005/3. 26.

${ }^{4} \mathrm{http} / / /$ www.echr.coe.int/NR/rdonlyres/B21D260B-3559-4FB2-A629-881C66DC3B2F/0/CountryStatistics01012009.pdf

${ }^{5}$ GRÁD András: A strasbourgi emberi jogi bíráskodás kézikönyve, Strasbourg Bt., Budapest, 2005, 56.

${ }^{6}$ Forrás: http://www.europatanacs.hu/index.php?workSpace=pages\&id=45\&langId=1

${ }^{7}$ NEMES Imre: A méltányos birósági eljáráshoz való jog az Emberi Jogok Európai Egyezményében, Forrás:
} http://www.drnemesimre.hu/doc/Prokator04.pdf

${ }^{8}$ 30979/96 sz. kérelem, 43. §.

${ }^{9}$ Közigazgatási és Igazságügyi Minisztérium (Répássy Róbert igazságügyért felelős államtitkár), Tájékoztató az Országos Igazságszolgáltatási Tanács részére az Emberi Jogok Európai Bírósága elött folyamatban lévő - a magyar bíróságok eljárásával kapcsolatos - állampolgári kérelmek intézéséröl, aktuális fejleményeiről (XXNBSKFO/1149-2/2011.) 2. Forrás: http://www.mabie.hu/sites/mabie.hu/files/Ejb.pdf

${ }^{10}$ Közigazgatási és Igazságügyi Minisztérium i.m. 2.

${ }^{11}$ OROSZ Árpád: A magyarországi polgári perek az Emberi Jogok Európai bírósága elött, Acta Humana, 2007/4. 9 .

${ }^{12}$ Az Alkotmánybíróság 6/1998. (III. 11.) AB határozata.

${ }^{13}$ GRÁD i.m. 240.

${ }_{14}^{14}$ Rolf Gustafson v. Sweden ügy, 1997. július 1-i ítélet.

${ }^{15}$ GRÁD i.m. 260.

16 SZABÓ Győző - NAGY Gábor: Tanulmányok az Emberi Jogok Európai Egyezménye legfontosabb rendelkezéseihez kapcsolódó strasbourgi esetjogról, hvgorac, Budapest, 1999, 103.

${ }^{17}$ SZABÓ - NAGY i.m. 103.

18 KONDOROSI Ferenc: Az emberi jogok védelmének új kérdései, Emberi Jogok Magyar Központja Közalapítvány, Budapest, 2006, 51.

${ }^{19}$ NEMES i.m. Forrás: http://www.drnemesimre.hu/doc/Prokator04.pdf

${ }^{20}$ OROSZ i.m. 12.

${ }^{21}$ WELLER Mónika - TEPLÁN Attila, Magyar ügyek Strasbourgban, Acta Humana, 2000/41-42. 109.

${ }^{22}$ SZABÓ - NAGY i.m. 113. (Pretto és társai ügyében 1983. december 8-i ítélet 27. pont, Sutter ügyben 1984. február 22-i ítélet 31-34. pont)

${ }^{23}$ SZABÓ - NAGY i.m. 113. (Axen ügyben 1983. december 8-i ítélet 29-30 pont)

${ }^{24}$ 44746/04 sz. kérelem, 2008. február 5-i ítélet.

${ }^{25}$ 44885/04. sz. kérelem, 2007. november 20-i ítélet.

${ }^{26}$ 14962/03. sz. kérelem, 2006. október 3-i ítélet.

${ }^{27}$ WELLER - TEPLÁN i.m. 108.

${ }^{28}$ NEMES i.m. http://www.drnemesimre.hu/doc/Prokator04.pdf

${ }^{29}$ GRÁD i.m. 284.

${ }^{30}$ NEMES i.m. http://www.drnemesimre.hu/doc/Prokator04.pdf

${ }^{31}$ Közigazgatási és Igazságügyi Minisztérium i.m. 3.

${ }^{32}$ Buchholz kontra Németország ügyben 1981. május 6-i ítélet 47-48. pont.

${ }^{33}$ KARSAI i.m. 39.

${ }^{34}$ 60307/00 sz. kérelem, 2004. március 23-i elfogadhatósági határozata.

${ }^{35}$ 60297/00 sz. kérelem, 2004. március 30-i ítélet, 60-62. pont.

${ }^{36}$ Közigazgatási és Igazságügyi Minisztérium i.m. 4.

${ }^{37}$ NEMES i.m. Forrás: http://www.drnemesimre.hu/doc/Prokator04.pdf

${ }^{38}$ KARSAI i.m. 40.

39 39382/06 sz. ügye, 2010. november 30-i kelt ítélet.

${ }^{40}$ A Legfelsőbb Bíróság Nemzetközi Kapcsolatok és Európai Jogi Irodájának Hírlevele, I/7. 28. Forrás: http://www.lb.hu/ 
${ }^{41}$ 32367/96 sz. kérelem, 2000. október 5-i kelt ítélet.

${ }^{42}$ KARSAI, i.m. 41.

${ }^{43}$ http://www.lb.hu/embjog/ej007100.html 